\title{
Research Note: \\ Effects of human activities on the Yangtze River suspended sediment flux into the estuary in the last century
}

\author{
S.L. Yang ${ }^{1}$, Z. Shi ${ }^{2}$, H.Y. Zhao ${ }^{1}$, P. Li ${ }^{1}$, S.B. Dai ${ }^{1}$ and A. Gao ${ }^{1}$ \\ ${ }^{1}$ State Key Lab of Estuarine and Coastal Research, East China Normal University, Shanghai 200062, China \\ ${ }^{2}$ School of Naval Architecture, Ocean and Civil Engineering, Shanghai Jiaotong University, 1954 Huashan Road, Shanghai 200030, China \\ E-mail for corresponding author: slyang@sklec.ecnu.edu.cn; shilunyang@hotmail.com
}

\begin{abstract}
The surface erosion area in the Yangtze River basin increased from $364 \times 10^{3} \mathrm{~km}^{2}$ in the 1950 s to $707 \times 10^{3} \mathrm{~km}^{2}$ in 2001 due to a great increase in population. Based on the regression relationship between surface erosion area and population, the surface erosion area was predicted to be about $280 \times 10^{3} \mathrm{~km}^{2}$ at the beginning of the $20^{\text {th }}$ century. The sediment yield, which increased by about $30 \%$ during the first six decades of the $20^{\text {th }}$ century, was closely related to the surface erosion area in this river basin. The Yangtze annual suspended sediment flux into the estuary was about $395 \times 10^{6} \mathrm{t} \mathrm{a}^{-1}$ at the beginning of the century, and this gradually increased to an average of $509 \times 10^{6} \mathrm{ta}^{-1}$ in the $1960 \mathrm{~s}$. The increase in the suspended sediment flux into the estuary was accelerated in the 1950s and the 1960s due to the rapid increase in population and land use immediately after the Second World War and the Liberation War. After the riverine suspended sediment flux reached its maximum in the $1960 \mathrm{~s}$, it decreased to $<206 \times 10^{6} \mathrm{t} \mathrm{a}^{-1}$ in 2003 . Construction of dams was found to be the principal cause for this decreasing trend because, during the same period, (a) the riverine water discharge did not show a decreasing trend, (b) water diversion was not influential and (c) sedimentation in lakes and canals of the middle and lower reaches did not increase. The total storage capacity of reservoirs has increased dramatically over the past half century. The amount of sediment trapped in reservoirs has increased to more than half a billion $t a^{-1}$. As a result, the suspended sediment flux into the estuary dramatically decreased, even though the sediment yield from many areas of the basin increased in recent decades. Human activities gradually increased the suspended sediment flux into the estuary before the 1960s and then rapidly decreased it. The last century was a period when the Yangtze suspended sediment flux into the estuary was dramatically affected by human activities.
\end{abstract}

Keywords: riverine sediment flux, human activities, surface erosion, dam, Yangtze (Changjiang) River

\section{Introduction}

Riverine sediment flux into an estuary usually governs the $10^{\circ} \sim 10^{2}$ year evolution of deltas (Innocenti and Pranzini, 1993; Fanos, 1995; Guillen and Palanques, 1997; Barusseau et al., 1998; Stanley and Warne, 1998; Carriquiry and Sánchez, 1999; Ly, 1980; Panin and Jipa, 2002; Yang et al., 2003a). It also affects short-term sediment transport in the estuarine and coastal areas (Yang et al., 2003b; Shi, 2004). Human activities have strongly influenced the riverine sediment supply to the estuary in many rivers during the 19th and 20th centuries (Guillen and Palanques, 1997; Trenhaile, 1997; Walling, 1999; Milliman, 2001). Compared with the scientific knowledge of many rivers such as the Nile in Egypt (Fanos, 1995; Stanley and Warne, 1998), the
Ebro in Spain (Guillen and Palanques, 1997; SanchezArcilla et al., 1998), the Mississippi (Coleman et al., 1998) and the Colorado River in USA (Carriquiry and Sánchez, 1999), the Niger River in Niger (Abam, 1999), the Senegal River in Senegal (Barusseau et al., 1998), the Yellow River in China (Yang et al., 1998), and the Volta River in Ghana (Ly, 1980), less is known of the Yangtze (Changjiang), especially in terms of its history before the 1950s. The measurement of sediment flux in the Yangtze River began in the 1950s. Although the recent decrease in Yangtze River suspended sediment load has preliminarily been revealed and related to human activities (Yang et al., 2002), further studies are needed. The primary objective of this paper is to examine the effects of human activities on the Yangtze River 
suspended sediment flux into the estuary in the last century.

\section{Physical settings and data collection}

The Yangtze originates from the Tibetan Plateau at an elevation of more than $5000 \mathrm{~m}$. It flows eastward for 6300 $\mathrm{km}$ before entering the East China Sea. Its catchment covers an area of $1.94 \times 10^{6} \mathrm{~km}^{2}$ and currently has a population of about 400 million. Its mean annual water flux is $908 \times 10^{9} \mathrm{~m}^{3}$ (1950-2003) and its annual suspended sediment flux is $422 \times 10^{6}(1951-2003)$. The mean annual precipitation and evapotranspiration for the basin are 1000-1400 mm and 700-800 mm respectively (Shen, 1986). The Yangtze ranks third in the world in length (Wang and Zhu, 1994), ninth in catchment area (Chen and Gupta, 2001), fourth in sediment flux and fifth in water flux (Eisma, 1998), and probably ranks first for population. The upper reaches of the river end at Yichang, $1840 \mathrm{~km}$ away from the estuary. The bed level of the main stream at Yichang is about $60 \mathrm{~m}$ above the estuary, suggesting that the gradient of the trunk stream is more than one magnitude order higher in the upper reaches than in the middle and lower reaches. The upper reaches account for $52 \%$ of the catchment area. There are many lakes scattered throughout the middle and lower reaches. Among them, Lake Dongting and Lake Poyang are the two largest. These lakes, especially Lake Dongting, act as sinks for riverine sediment. The tidal limit of the Yangtze estuary is at Datong. Datong accounts for $93 \%$ of the catchment area (Fig. 1). The water and sediment fluxes at Datong are 2.04 and 0.86 times that at Yichang respectively (Yang et al., 2002).

Data on water and sediment fluxes for the river were provided by the Yangtze River Water Conservancy Committee, Ministry of Water Conservancy of China. Data for population, surface erosion area and sediment yield were derived from different sources in the literature. SPSS software was employed for regression analysis.

\section{Results and discussions}

THE TIME SERIES OF ANNUAL DISCHARGE

Annual discharge was measured in 1923-1924, 1930, 19351937, 1948 and since 1950 at the Datong Hydrological Station. Annual discharge was therefore not available for most of the first half of the 20th century. Fortunately, annual flow discharges has been measured since 1865 at the Hankou Hydrological Station where the Hanjiang River flows into the trunk stream (Fig. 1) of the Yangtze. Although Hankou is about $500 \mathrm{~km}$ upstream from Datong, its annual flow is significantly correlated with the annual flow at Datong $(\mathrm{r}=0.95 P<0.001)$. Thus the missing annual flow discharges for Datong could be estimated by utilizing the regression relationship for annual flow between Hankou and Datong.

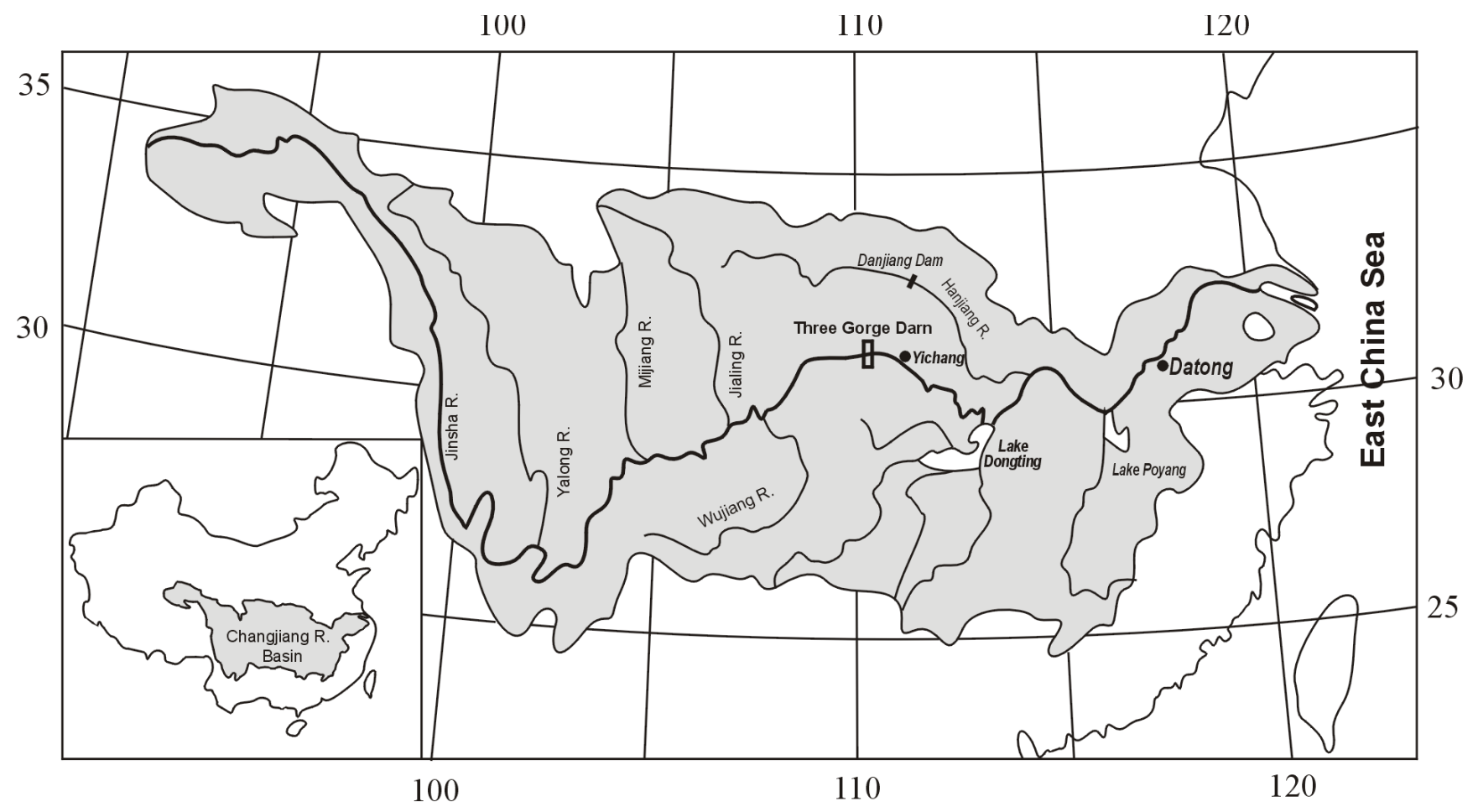

Fig. 2. The Yangtze River basin in China. 


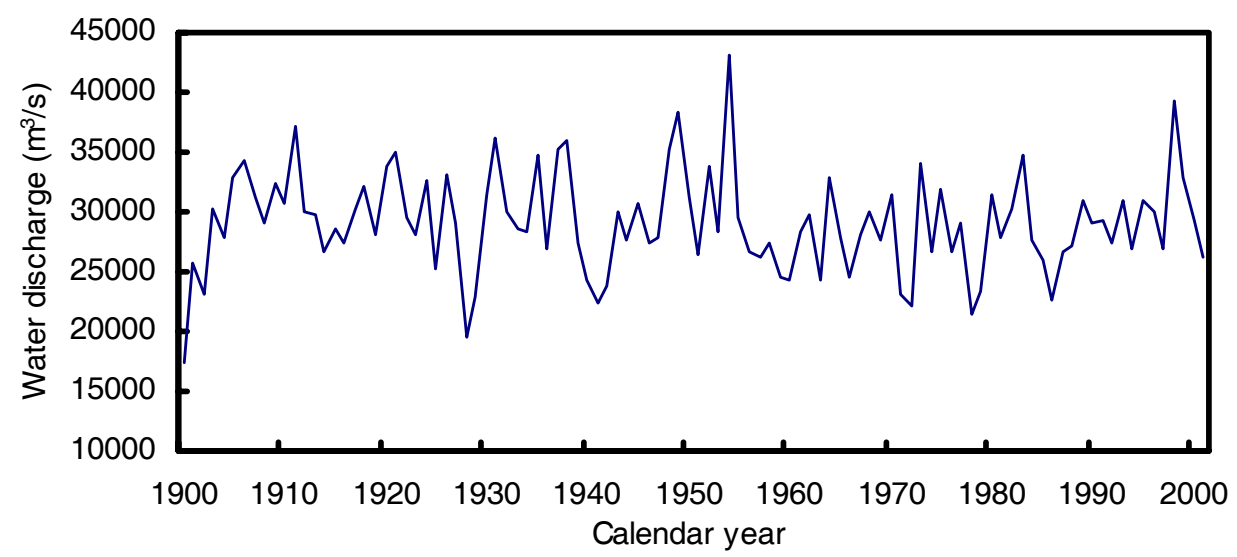

Fig. 1. Annual flow discharges at Datong (observed in 1923-1924, 1930, 1935-1937, 1948 and since 1950; data for the missing years were estimated using the regression between flows at Datong and Hankou.

A time series of annual flow discharge at Datong was reconstructed for the whole 20th century (Fig. 2). According to this time series, the annual flow discharge increased by $1.5 \%$ from 1900 to 1949 .

\section{INCREASE IN SEDIMENT FLUX DUE TO}

\section{DEFORESTATION FROM THE 1900S TO THE $1960 \mathrm{~S}$}

The surface erosion area in the Yangtze catchment has nearly doubled over the past five decades. The surface erosion area was estimated to be $364 \times 10^{3} \mathrm{~km}^{2}$ in the $1950 \mathrm{~s}$ (Shi, 1999; Zhang and Zhu, 2001) and $707 \times 10^{3} \mathrm{~km}^{2}$ in 2001 (CRWCCWCMC, 2002). The increase in surface erosion area is attributed to the increase in population. The population of the river basin was 178 million in 1949 and increased to nearly 400 million in 2001(Zhang, 2000). Assuming that $364 \times 10^{3} \mathrm{~km}^{2}$ represents the surface erosion area in the mid-1950s and the increase in surface erosion was proportional to the increase in population from 1949 to 2001, the surface erosion area was estimated to be about
$319 \times 10^{3} \mathrm{~km}^{2}$ in 1949 , and the relationship between surface erosion area (A) and population $(\mathrm{P})$ is

$$
\mathrm{A}=0.001748 \mathrm{P}+9701
$$

where A represents surface erosion area in $\mathrm{km}^{2}$ and $\mathrm{P}$ population. The surface erosion area at the beginning of the 20 th century is estimated to be about $280 \times 10^{3} \mathrm{~km}^{2}$, because the population at that time was 155 million.

Although the sediment yields measured for the gauging stations within the basin are highly variable because of natural diversity in the catchment, this variability is reduced when the data are integrated (Lu and Higgitt, 1999). Averaged over the basin, the sediment yield was $3980 \mathrm{t} \mathrm{km}^{-2} \mathrm{a}^{-1}$ (Table 1). The coefficient of the independent variable $\mathrm{A}$ in the regression equation in Fig. 3 suggests a similar sediment yield. The very good correlation shown in Fig. 3 suggests that the differences in sediment yield among the subcatchments are very low. The total surface erosion area in Table 2 and Fig. 3 amounts to $81 \%$ of the whole

Table 1. Distribution of area of surface erosion and sediment yield among different intensity types in the Yangtze River basin in 1985 (based on Shi, 1998)

\begin{tabular}{lccc}
\hline $\begin{array}{l}\text { Intensity types of } \\
\text { surface erosion }\left(\mathrm{t} / \mathrm{km}^{2} \cdot a\right)\end{array}$ & $\begin{array}{l}\text { Sediment yield rate } \\
\left(t \mathrm{~km}^{-2} \mathrm{a}^{-1}\right)\end{array}$ & $\begin{array}{l}\text { Area of surface erosion } \\
\left(10^{3} \mathrm{~km}^{2}\right)\end{array}$ & $\begin{array}{c}\text { Annual sediment yield surface erosion } \\
\left(10^{6} \mathrm{t}\right)\end{array}$ \\
\hline Very low-grade & $500-2500$ & 210 & 247 \\
Low-grade & $2500-5000$ & 190 & 658 \\
Middle-grade & $5000-8000$ & 103 & 652 \\
High-grade & $8000-13500$ & 40.8 & 417 \\
Very high-grade & $>13500$ & 18.6 & 265 \\
Total & 3980 & 562 & 2239 \\
\hline
\end{tabular}




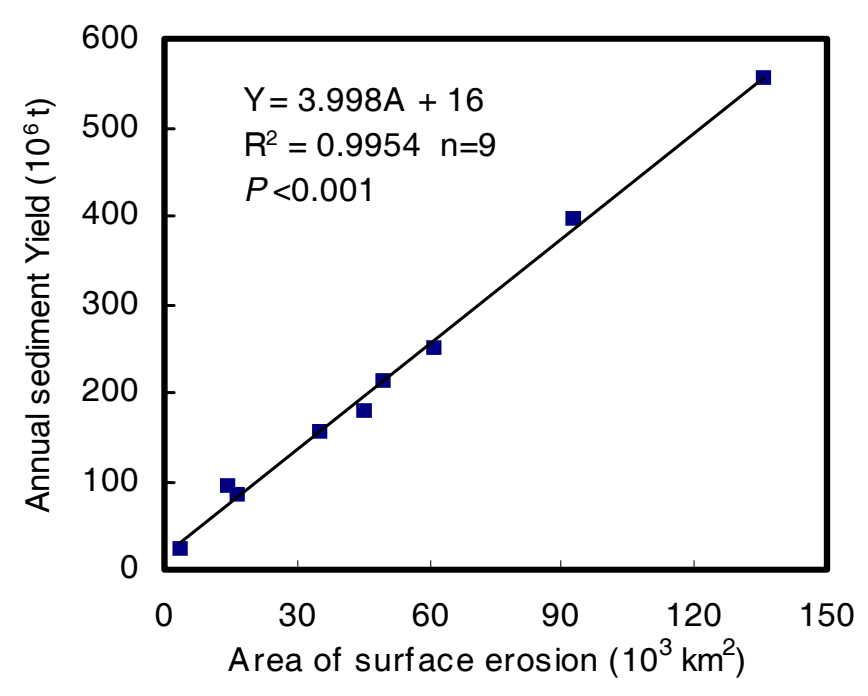

Fig. 3. Regression between area of surface erosion (A) and annual sediment yield (Y) (data in Table 2).

catchment. In Anhui Province around Datong in the lower reaches where the surface erosion area was $33.6 \times 10^{3} \mathrm{~km}^{2}$ ( $6.0 \%$ of the total catchment area), the sediment yield rate, $2054 \mathrm{t} \mathrm{km}^{-2} \mathrm{a}^{-1}$ on average, was lower than those in Table 2 and Fig. 3 (Zhang et al., 1999). On the other hand, in the Three Gorges region where the surface erosion area was $34.6 \times 10^{3} \mathrm{~km}^{2}(6.2 \%$ of the total catchment), the sediment yield rate, $5780 \mathrm{t} \mathrm{km}^{-2} \mathrm{a}^{-1}$ on average, was higher than those in Table 2 and Fig. 3. Because the surface erosion area in these two regions was only $12 \%$ of the total, the spatial variation in sediment yield rate was assumed to be low. In view of this, the regional difference in sediment yield was ignored when predicting the sediment yield before the 1950s. There will be a 'natural' background sediment yield in the catchment. Table 1 suggests that surface erosion is defined as an area where sediment yield rate is $\geq 500 \mathrm{t} \mathrm{km}^{-2} \mathrm{a}^{-1}$. In other words, the sediment yield rate is $<500 \mathrm{t} \mathrm{km}^{-2} \mathrm{a}^{-1}$ in the rest of the catchment. In the Yangtze catchment, the annual sediment yield on forestland was found to be $6 \mathrm{t} \mathrm{km}^{-2}$ (Li et al., 2002). The forest cover in the Yangtze catchment was $60-80 \%$ in the distant past and decreased to $22 \%$ in 1957 and 10\% in 1986 (Zhang and Zhu, 2001). Assuming (a) the forest cover was $30 \%$ in 1900 and $25 \%$ in 1949 and (b) the average sediment yield for the remaining uncleared land is $300 \mathrm{t} \mathrm{km}^{-2} \mathrm{a}^{-1}$, the average sediment yield for the uncleared land in the basin was $196 \mathrm{t} \mathrm{km}^{-2} \mathrm{a}^{-1}$ in 1900, 211 $\mathrm{t} \mathrm{km}^{2} \mathrm{a}^{-1}$ in 1949 and $219 \mathrm{t} \mathrm{km}^{-2} \mathrm{a}^{-1}$ in the 1950s, which was comparable to the corresponding sediment yield in the United States (Langbein and Schumm, 1958). Based on the above assumption and using the catchment area above Datong Hydrological Station $\left(1.81 \times 10^{6} \mathrm{~km}^{2}\right)$, the annual sediment yield would be $196 \times\left(\begin{array}{l}1810000-280000) \\ 0\end{array}\right.$ $+3980 \times 280000=1.414 \times 10^{9} \mathrm{t}$ in $1900,211 \times(1810000$ $-319000)+3980 \times 319000=1.584 \times 10^{9} \mathrm{t}$ in 1949 , and $219 \times(1810000-364000)+3980 \times 364000=1.765$ $\times 10^{9} \mathrm{t}$ in the $1950 \mathrm{~s}$.

Only part of the sediment derived from surface erosion enters the river system, including waterways, lakes and reservoirs. The sediment entering the river system either flows into the estuary or settles down in the river system. To estimate the missing sediment flux into the estuary before the 1950s, the amount of sediment entering the river system and the amount of sediment deposited in the river system need to be known. In the $1950 \mathrm{~s}$, the sediment flux into the estuary was $466 \times 10^{6} \mathrm{t} \mathrm{a}^{-1}$ and the deposition in lakes and river channels was $195 \times 10^{6} \mathrm{ta}^{-1}$, on average, and deposition in reservoirs can be effectively ignored because few dams had been constructed by then (Zhu, 2000). Therefore, the

Table 2. Area of surface erosion and sediment yield in subcatchments of the Yangtze in 1985

\begin{tabular}{lccl}
\hline Subcatchments & $\begin{array}{c}\text { Area of surface } \\
\text { erosion }\left(10^{3} \mathrm{~km}^{2}\right)\end{array}$ & $\begin{array}{c}\text { Annual sediment yield } \\
\left(10^{6} \mathrm{t}\right)\end{array}$ & Data sources \\
\hline Jinshajiang R. & 135.4 & 557.4 & Shi, 1999 \\
Jialinjiang R. & 92.5 & 397 & Shi, 1999 \\
Hanjiang R. & 61.0 & 250 & He, 1997 \\
Minjiang R. & 49.2 & 215 & Shi, 1999 \\
Four rivers into Lake Dongting & 45.3 & 180 & Zhang et al., 1999 \\
& & & Zhang and Zhu, 2001 \\
Five rivers into Lake Poyang & 35.2 & 155 & Zhang et al., 1999 \\
Tuojiang R. & 16.3 & 84.1 & Shi, 1999 \\
Wujiang R. & 14.6 & 95.4 & Shi, 1999 \\
Chishuihe R. & 3.86 & 23.6 & Shi, 1999 \\
Total & 453.4 & 1958 & \\
\hline
\end{tabular}


ratio of the sediment entering the river system to the sediment yield was $\left(466 \times 10^{6} \mathrm{t}+195 \times 10^{6} \mathrm{t}\right) / 1.765 \times 10^{9}$ $\mathrm{t}=0.374$, which is similar to the ratio of 0.34 from Zhu (2000). This ratio can be expected to be sensitive to changing land use. However, taking the whole catchment, the different land uses can be expected to change nearly proportionally with the total surface erosion area, and the influence on the ratio is expected to be limited. Using a ratio of 0.36 , the average of this study and that of Zhu (2000), the sediment entering the river system was predicted to be $509 \times 10^{6} \mathrm{t}$ in 1900 and $570 \times 10^{6} \mathrm{t}$ in 1949 .

The lakes and channels in the middle and lower reaches acted as an adjustor for the riverine sediment. The greater the amount of sediment supplied to them, the higher the deposition rate. The deposition was 195,108 and $\approx 0 \times 10^{6}$ $\mathrm{t} \mathrm{a}^{-1}$ when the sediment supplied to them was 661,510 and $\approx 300 \times 10^{6} \mathrm{t} \mathrm{a}^{-1}$, respectively (unpublished data of the authors), which suggests a regression equation $\mathrm{D}=0.5385 \mathrm{~S}$ $163, \mathrm{r}^{2}=0.999, P<0.001$, where $\mathrm{D}\left(10^{6} \mathrm{ta}^{-1}\right)$ is the deposition rate and $\mathrm{S}\left(10^{6} \mathrm{t} \mathrm{a}^{-1}\right)$ is sediment supply, respectively. According to this equation, the deposition was $111 \times 10^{6} \mathrm{t}$ in 1900 and $144 \times 10^{6} \mathrm{t}$ in 1949. Thus, the suspended sediment flux into the estuary was about $398 \times 10^{6} \mathrm{t} \mathrm{a}^{-1}$ in 1900 and $426 \times 10^{6} \mathrm{t} \mathrm{a}^{-1}$ in 1949 , if the influence of water discharge is not considered.

In natural river systems, sediment flux is positively correlated to flow discharge (Chernicoff and Venkatakrishnan, 1995). Taking the $1.5 \%$ increase of flow discharge into account, the suspended sediment flux was predicted to be $395 \times 10^{6} \mathrm{t} \mathrm{a}^{-1}$ in 1900 and 429 in 1949, respectively. Assuming that the suspended sediment flux increased progressively from 1900 to 1949 , the decadal suspended sediment flux would be as shown in Fig. 4. The sharp increase in annual sediment flux in the 1950s $\left(466 \times 10^{6} \mathrm{ta}^{-1}\right)$ and in the $1960 \mathrm{~s}\left(509 \times 10^{6} \mathrm{ta}^{-1}\right)$ was likely caused by the population boom after the Second World War and the Liberation War which ended in 1949.

\section{DECREASE IN SEDIMENT FLUX DUE TO DAM CONSTRUCTIONS SINCE THE 1970 S}

Dam construction in the Yangtze River basin began to flourish in the late 1950s, much later than on rivers of other countries such as the Nile (Fanos, 1995; Stanley and Warne, 1998), the Ebro (Guillen and Palanques, 1997) and the Colorado (Carriquiry and Sánchez, 1999). Up to now, nearly 50000 dams have been constructed in the Yangtze River basin. Along with the rapid increase in the cumulative reservoir storage capacity, more and more riverine sediment was trapped in the reservoirs. For example, in the upper reaches (upstream from Yichang), the total amount of deposition in reservoirs was 2.85 and $19.1 \times 10^{6} \mathrm{t} \mathrm{a}^{-1}$ in the 1950 s and the 1960s, respectively. The largest reservoir put into operation in the 20th century, the Danjiangkou Reservoir (Fig. 1), with a storage capacity of $17.45 \times 10^{9} \mathrm{~m}^{3}$ began to impound water in 1959. From 1960 to 1994 , $1.41 \times 10^{9} \mathrm{~m}^{3}$ of sediment was trapped by this reservoir (www.cjh.com.cn, 2003), giving a mean depositional rate $53.3 \times 10^{6} \mathrm{t} \mathrm{a}^{-1}$

The total storage capacity of these reservoirs amounted to approximately $200 \times 10^{9} \mathrm{~m}^{3}$ by the end of 2003 . This represents $22 \%$ of the annual flow discharge into the estuary. The total amount of sediment trapped by the reservoirs was positively related to the total storage capacity (Fig. 5). Annual suspended sediment flux into the estuary has shown a significant decrease since the late 1960s (Fig. 6). Annual suspended sediment flux in the $1990 \mathrm{~s}, 343 \times 10^{6} \mathrm{t} \mathrm{a}^{-1}$, was one-third lower than the annual suspended sediment flux in

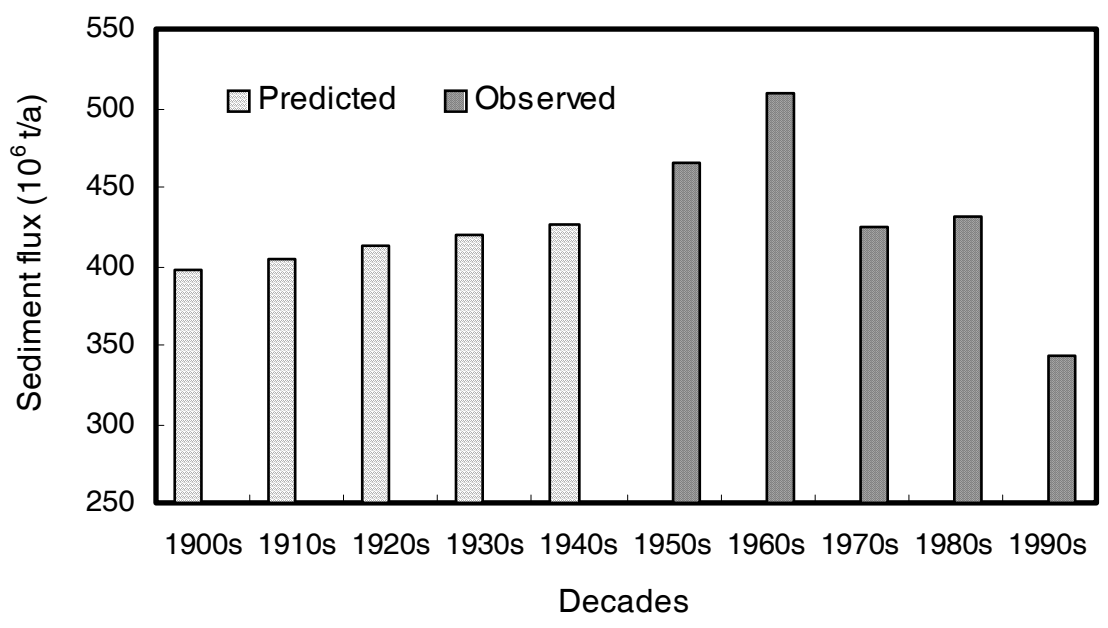

Fig. 4. Decadal suspended sediment flux into the estuary. 


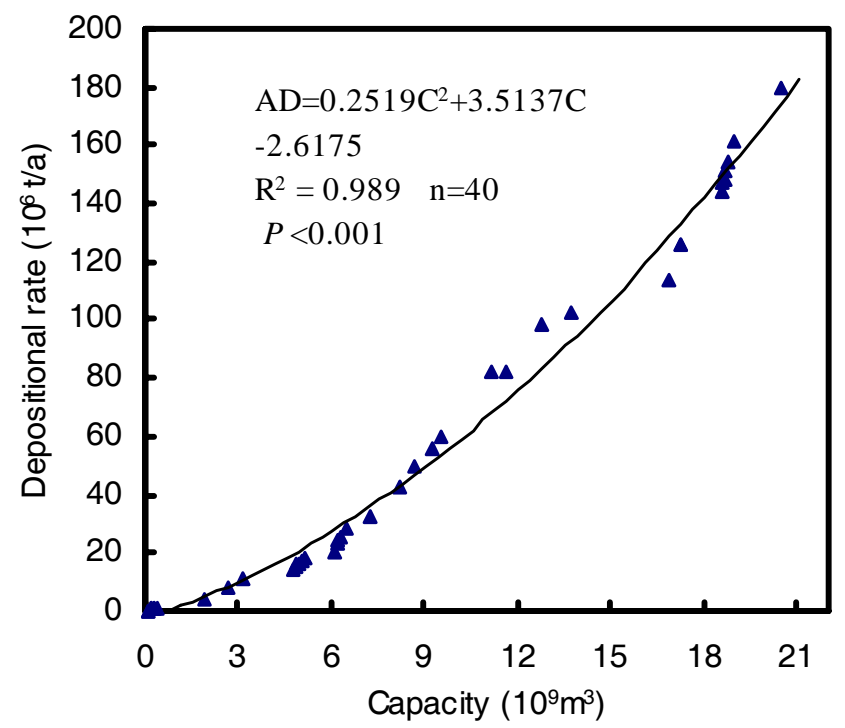

Fig. 5. Correlation between deposition rate and storage capacity of the reservoirs in the upper Yangtze.

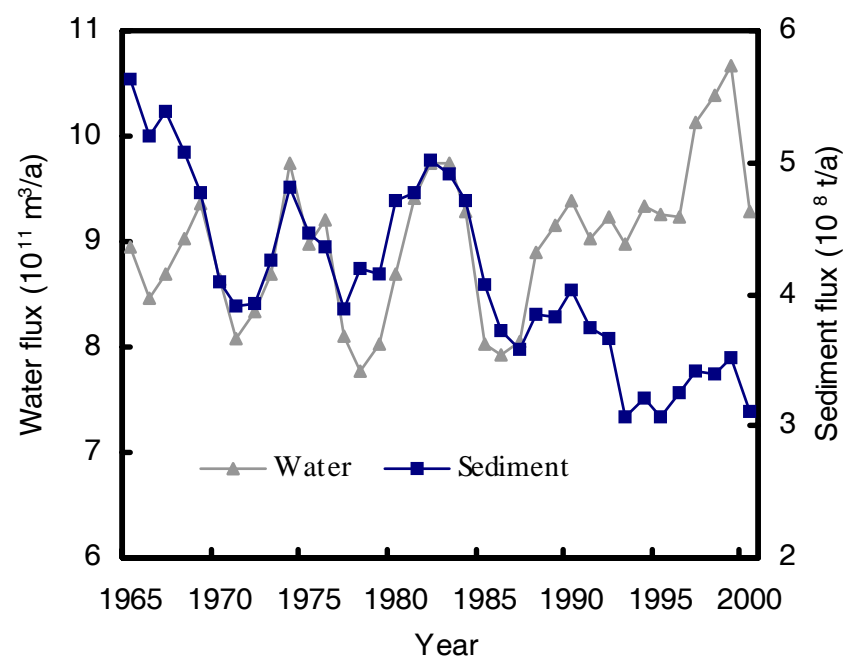

Fig. 6. Three-year running water and suspended sediment fluxes into the estuary.

the 1960s, and it decreased to 276,275 and $206 \times 10^{6} \mathrm{t} \mathrm{a}^{-1}$ in 2001, 2002 and 2003, respectively.

The inter-annual fluctuations in annual suspended sediment flux can be attributed to cyclic changes in climate, because they were in phase with the fluctuations of the annual water flux (Fig. 6). Nevertheless, the decreasing trend in annual suspended sediment flux was caused by human activities because neither the annual water flux showed a decreasing trend nor the deposition in the lakes and channels in the river system showed an increasing trend.
Along with the dramatic increase in number of dams and total storage capacity of reservoirs, the annual deposition in the reservoirs increased from a few million tons in the 1950s to more than 500 million tons in recent years. Since the late 1960s, dam construction has replaced land use as the dominant factor influencing the riverine suspended sediment flux into the estuary. In recent years, reservoirs have replaced the estuary as the principal sink for riverine sediments from the Yangtze.

Sediment extraction from river beds was also responsible for the decrease in riverine sediment flux. The Economic Reformation in China begun in the early 1980s, greatly intensified construction activity and promoted the demand for sand material in the Yangtze River basin. The sediment extraction from the trunk stream of the middle and lower Yangtze was estimated to be $40 \times 10^{6} \mathrm{t} \mathrm{a}^{-1}$ in the early $1980 \mathrm{~s}$ to $80 \times 10^{6} \mathrm{t} \mathrm{a}^{-1}$ in the late 1990s (Chen, 2004). In fact, sand extraction was also observed in the upper Yangtze and many tributaries. Although it is unclear how much suspended sediment was lost to compensate for sand extraction, the amount was likely to be considerable.

The Yangtze suspended sediment flux into the estuary is expected to decrease to less than $200 \times 10^{6} \mathrm{t} \mathrm{a}^{-1}$ in the coming decades due to the construction of the widely publicised Three Gorges Dam as well as other new dams. In addition, sediment extraction in the Yangtze will continue although the amount of sediment extraction will be controlled, for example, to $34 \times 10^{6} \mathrm{t} \mathrm{a}^{-1}$ in the middle and lower reaches (Chen, 2004).

\section{Conclusions}

Human activities, especially deforestation and dam construction, dramatically changed the Yangtze River suspended sediment flux into the estuary in the last century. The continuous increase in population enhanced land-use change and intensified surface erosion. The sediment yield was proportional to the surface erosion area. Along with the expansion of the surface erosion area, the suspended sediment flux into the estuary increased from less than $400 \times 10^{6} \mathrm{t} \mathrm{a}^{-1}$ at the beginning of the 1900 s to more than $500 \times 10^{6} \mathrm{t} \mathrm{a}^{-1}$ in the $1960 \mathrm{~s}$. Dam construction began to replace land use as a dominant factor controlling the suspended sediment flux after the late 1960s, and has been responsible for the decreasing the suspended sediment flux into the estuary. The 1960 s were probably the decade when the suspended sediment flux of the Yangtze River reached its maximum. The last century is likely to be recognised as a special period when human activities changed the suspended sediment flux from the Yangtze River into the estuary most dramatically. 


\section{Acknowledgements}

This study was supported by the National Great Science Projects (2002CB412407), the National Science Fund for Distinguished Young Scholars (Estuarine and Coastal Science 40225014) and the Natural Science Foundation of China (No. 40076027). Prof. D.E. Walling and Managing Editor J.S.G. McCulloch are thanked for their comments and help in improving the manuscript.

\section{References}

Abam, T.K.S., 1999. Impact of dams on the hydrology of the Niger Delta. Bull. Eng. Geol. Environ., 57, 239-251.

Barusseau, J.P., Ba, M. and Descamps, C., 1998. Morphological and sedimentological changes in the Senegal River estuary after the construction of the Diama dam. J. Afr. Earth Sci., 26, 317326.

Carriquiry, J.D. and Sánchez, A., 1999. Sedimentation in the Colorado River delta and Upper Gulf of California after nearly a century of discharge loss. Mar. Geol., 158, 125-145.

Chen, X., 2004. Human impacts on sediment discharge from the Yangtze into the estuary: history and future perspective. Abstracts IAG Yangtze Fluvial Conference (June 24-27, Shanghai, China), 4-5.

Chen, Z. and Gupta, A., 2001. The Yangtze River: an introduction (Editorial). Geomorphology 41, 73-75.

Chernicoff, S. and Venkatakrishnan, R., 1995. Geology: An Introduction to Physical Geology. Worth Publishers, Inc., New York, USA. 593pp.

Coleman, J.M., Roberts, H.H. and Stone, G.W., 1998. Mississippi River delta: an overview. J. Coast. Res., 14, 698-716.

CRWCCWCMC, 2002. Changjiang River Almanac. Wuhan: Changjiang River Almanac Press.

Eisma, D., 1998. Intertidal Deposits: River Mouths, Tidal Flats and Coastal Lagoons. Boca Raton, Florida: CRC Press. 459pp.

Fanos, A.M., 1995. The impact of human activities on the erosion and accretion of the Nile Delta coast. J. Coast. Res., 11, 821833.

Guillen, J. and Palanques, A., 1997. A historical perspective of the morphological evolutions in the lower Ebro River. Environ. Geol., 30, 174-180.

He, S., 1997. Characteristics of soil erosion in Hanjiang valley and possible countermeasures. Resources and Enviroment in Yangtze Valley 6, 271-276 (in Chinese with English abstract).

Innocenti, L. and Pranzini, E., 1993. Geomorphological evolution and sedimentology of the Ombrone River Delta, Italy. J. Coast. Res., 9, 481-493.

Langbein, W.B. and Schumm, S.A., 1958. Yield of sediment in relation to mean annual precipitation. Trans. Amer. Geophys. Un., 39, 1076-1084.

Li, Y., Deng, J. and Sun, Z., 2002. Destruction of ecological environment and flood and sediment disaster in Yangtze River basin. J. Soil Water Conserv., 16, 31-35.

Lu, X.X. and Higgitt, D.L., 1999. Sediment yield variability in the upper Yangtze, China. Earth Surf. Process. Landf., 24, 1077 1093.
Ly, C.K., 1980. The role of the Akosombo Dam on the Volta River in causing coastal erosion in central and eastern Ghana. Mar. Geol., 35, 323-332.

Milliman, J.D., 2001. Delivery and fate of fluvial water and sediment to the estuary: a marine geologist's view of European rivers. Scientia Marine 65 (Suppl.2), 121-132.

Panin, N. and Jipa, D., 2002. Danube river sediment input and itsinteraction with the north-western Black Sea. Estuar. Coast. Shelf Sci., 54, 551-562.

Sanchez-Arcilla, A., Jimenez, J.A. and Valdemoro, H.I., 1998. The Ebro Delta: morphodynamics and vulnerability. J. Coast. Res., 14, 754-772.

Shen, C.Y., 1986. A Pandect of China Climate. Bejing: China Science Press. 450pp (in Chinese).

Shi, D.M., 1999. Analysis of relationship between soil and water loss and flood disasters in Yangtze River basin. J. Soil Water Conserv., 5, 1-7 (in Chinese with an English abstract)

Shi, Z., 2004. Behavior of fine suspended sediment at the North Passage of the Changjiang Estuary, China. J. Hydrol., 293, 180190.

Stanley, D.J. and Warne, A.G., 1998. Nile Delta in its destruction phase. J. Coast. Res., 14, 794-825.

Trenhaile, A.S., 1997. Coastal Dynamics and Landforms. Clarendon Press. Oxford, UK. 365pp.

Walling, D.E., 1999. Linking land use, erosion and sediment yields in river basins. Hydrobiologia 410, 223-240.

Wang, Y. and Zhu, D., 1994. Coastal Geomorphology. Bejing: Higher Education Press. 244pp. (in Chinese)

www.cjh.com.cn,, 2003. Sediment Gazette in 2001. Changjiang River Hydrology Internet.

Yang, S.L., Belkin, I.M., Belkina, A.I., Zhao, Q.Y., Zhu, J. and Ding, X.D., 2003a. Delta response to decline in sediment supply from the Yangtze River: evidence of the recent four decades and expectations for the next half-century. Estuar. Coast. Shelf Sci., 57, 589-599.

Yang, S.L., Friedrichs, C.T., Shi, Z., Ding, P.X., Zhu, J. and Zhao, Q.Y., 2003b. Morphological response of tidal marsh, flats and channels of the outer Yangtze River mouth to a major storm. Estuaries 26, 1416-1425.

Yang, S.L., Zhao, Q.Y. and Belkin, I.M., 2002. Temporal variation in the sediment load of the Yangtze River and the influences of the human activities. J. Hydrol., 263, 56-71.

Yang, Z.S., Milliman, J.D., Galler, J., Liu, J.P. and Sun, X.G., 1998. Yellow River's water and sediment discharge decreasing steadily. Eos. Trans. Amer. Geophys. Un., 79, 589-592.

Zhang, D.Q., 2000. The effect of population activity on the changes in vegetation of Yangtze River valley since the ancient period of Spring and Autumn Warring States (700-211 B. C.). J. Plant Resour. Environ., 9, 47-53.

Zhang, J., Hu, H., Ruan, H. and Fang, Y., 1999. The present situation and control measures of soil and water loss in Yangtze River valley. J. Nanjing Forestry University 23, 17-21.

Zhang, S. and Zhu, C., 2001. Soil loss and its effect on flooding catastrophe in Yangtze drainage basin. J. Soil Water Conserv., 15, 9-16.

Zhu, J. Y., 2000. Variation of sediment transportation in the Yangtze River and the way for its reduction. J. Hydroelective Eng., 70, 38-48 (in Chinese). 